\title{
Detection of CMV DNA in bone marrow transplant recipients: plasma versus leucocyte polymerase chain reaction
}

\author{
P C Y Woo, S K F Lo, K Y Yuen, J S M Peiris, H Siau, E K W Chiu, R H S Liang, \\ T K Chan
}

\begin{abstract}
Aims-To compare the nested polymerase chain reaction (PCR) assay for the detection of cytomegalovirus (CMV) DNA in peripheral blood leucocytes and plasma obtained from heparinised blood; to determine the efficiency of various DNA extraction methods to minimise inhibition of plasma PCR and their effect on the sensitivity of plasma PCR; to determine the inhibitory effect of heparin, dextran, and EDTA on the CMV PCR assay.

Methods-217 heparinised blood specimens from 58 bone marrow transplant patients were processed and the sensitivities and specificities of the PCR assays using peripheral blood leucocytes and plasma (with simple, Instagene, and Geneclean extraction methods) were compared to those of conventional CMV culture. In a separate experiment, dilutions of heparin, dextran, and EDTA were included in PCR assays.

Results-The detection of CMV DNA using peripheral blood leucocytes for PCR assay was significantly more sensitive $(100 \%)$ than when using plasma $(60 \%)$. Instagene and Geneclean extraction removed inherent inhibition but did not improve the sensitivity of the plasma PCR reaction. Heparin had an inhibitory effect on PCR.

Conclusions-PCR assay using peripheral blood leucocytes is better than plasma for guiding the prescription of ganciclovir to bone marrow transplant patients. Heparin is inhibitory to the plasma PCR reaction. (F Clin Pathol 1997;50:231-235)
\end{abstract}

Keywords: cytomegalovirus; bone marrow transplant; polymerase chain reaction.

Bone marrow transplantation is one of the well recognised methods of treatment for malignant and non-malignant haematological diseases, some solid tumours, and metabolic disorders. Opportunistic infections that occur as a result of severe immunosuppression have always been a major cause of morbidity and mortality in bone marrow transplant patients. The nature of the infection is dependent on the period of time after bone marrow transplant. ${ }^{1}$ During the post-engraftment period (day 30 to day 100), human cytomegalovirus (CMV) is one of the most common pathogens in these patients, in whom the most serious manifestation is CMV pneumonitis. Although ganciclovir is recommended as the drug of choice for CMV disease, the decision on to whom it should be given and when has always been difficult because of its myelosuppressive properties. Giving ganciclovir prophylaxis to bone marrow transplant patients who were seropositive for CMV and to seronegative recipients who received bone marrow or blood products from seropositive donors has caused unnecessary bone marrow suppression. ${ }^{2}$ On the other hand, giving ganciclovir treatment only to those whose leucocyte or broncho-alveolar lavage (BAL) fluid tested positive for CMV by shell vial or conventional cell cultures (requiring at least two or 14 days, respectively) is too late as the disease has progressed to a more advanced stage. ${ }^{34}$ Hence newer diagnostic methods are required to minimise the overuse of ganciclovir prophylaxis and avoid withholding ganciclovir from those who would benefit from it. The development of rapid diagnostic methods to detect CMV DNA or antigen in plasma or buffy coat ${ }^{5}$ have facilitated earlier and more specific detection of CMV disease, and allowed the earlier institution of antiviral therapy.

In this longitudinal study two rapid methods, the nested polymerase chain reaction (PCR) assay for the detection of CMV DNA in plasma and peripheral blood leucocytes obtained from heparinised blood, were evaluated. Heparinised blood is frequently used for the detection of CMV DNA in plasma. ${ }^{6}$ However, heparin has been reported to be an inhibitor of PCR. ${ }^{8-10}$ We therefore investigated whether plasma obtained from heparinised blood is a suitable clinical specimen for the detection of CMV DNA by PCR. In addition the effects of another anticoagulant, ethylene diaminetetra-acetic acid (EDTA), and dextran, used in processing blood specimens, on the sensitivity of the PCR assay were studied. Three DNA extraction methods were also evaluated for their efficiency in removing PCR inhibitors from plasma.

\section{Methods}

This study included 217 specimens from 58 patients who underwent bone marrow transplantation in Queen Mary Hospital in Hong Kong (1991-93).

SPECIMEN COLLECTION AND PROCESSING Ten millilitres of heparinised blood (containing $500 \mathrm{U}$ heparin) were taken weekly from each 
patient from engraftment (absolute neutrophil count in peripheral blood $>0.5 \times 10^{9} / 1$ ) to day 100 after bone marrow transplantation or until the patient died. Plasma and buffy coat were extracted as follows. The blood was mixed with an equal volume of $6 \%(\mathrm{wt} / \mathrm{vol})$ dextran suspended in phosphate buffered saline (PBS) and was left at $37^{\circ} \mathrm{C}$ for 30 minutes for sedimentation. The upper cloudy layer was centrifuged at $1500 \mathrm{rpm}$ for 10 minutes and the supernatant fluid (that is the plasma) was stored at $-20^{\circ} \mathrm{C}$ before further processing. The pellet was suspended in hypotonic saline at $4^{\circ} \mathrm{C}$ for three minutes to lyse residual red blood cells, followed by rinsing in PBS. This last step was repeated and the sedimented peripheral blood leucocytes were harvested.

The plasma and peripheral blood leucocytes were further processed for the nested PCR assay. The plasma was filtered through a 0.45 $\mu \mathrm{m}$ filter and $100 \mu \mathrm{l}$ of the filtrate was digested with $100 \mu$ l of lysing buffer (containing proteinase $\mathrm{K}$ at $120 \mu \mathrm{g} / \mathrm{ml}$ ) at $56^{\circ} \mathrm{C}$ for one hour. The protease was inactivated at $95^{\circ} \mathrm{C}$ for 10 minutes. An aliquot, specified below, was used for plasma PCR. Peripheral blood leucocytes were resuspended in distilled water at a concentration of $2 \times 10^{6}$ cells $/ \mathrm{ml}$ and boiled for 15 minutes; $50 \mu \mathrm{l}$ of the boiled suspension was used for the leucocyte PCR.

CONVENTIONAL CMV CULTURE

Peripheral blood leucocytes were suspended in Eagle's minimal essential medium (EMEM), and inoculated onto a monolayer of human embryonic lung fibroblasts maintained in EMEM supplemented with $2 \%$ fetal calf serum, at a final concentration of $2 \times 10^{6}$ leucocytes $/ \mathrm{ml}$. The culture was incubated in $5 \% \mathrm{CO}_{2}$ at $37^{\circ} \mathrm{C}$ for up to six weeks. Inspection for cytopathic effects was carried out twice a week. All positive results were further confirmed by the detection of an immediate early antigen of $\mathrm{CMV}$ in cells using indirect immunofluorescence (Chemicon, USA). A confirmed positive CMV culture, representing positive viraemia in patients, was used as an indicator of CMV disease.

\section{EXTRACTION OF CMV DNA}

DNA of CMV in plasma was extracted by three different methods. In the simple extraction, 10 $\mu \mathrm{l}$ of supernatant fluid was used for plasma PCR after inactivation of protease and centrifugation. The remaining sample was split and processed separately using two commercial kits, following instructions from the manufacturer. In the Instagene extraction method, $50 \mu \mathrm{l}$ of the supernatant fluid was mixed with $200 \mu \mathrm{l}$ Instagene Purification matrix (Bio-Rad, California, USA) and incubated at $56^{\circ} \mathrm{C}$ for 30 minutes. The mixture was vortexed, heated to $100^{\circ} \mathrm{C}$ in a screw capped Eppendorf tube on a heat block for eight minutes, vortexed again, and centrifuged at $12000 \mathrm{rpm}$ for three minutes; $50 \mu \mathrm{l}$ of the supernatant fluid was used for plasma PCR. In the Geneclean extraction method, $50 \mu \mathrm{l}$ of the supernatant fluid was mixed with three volumes of $6 \mathrm{M}$ sodium iodide solution and $5 \mu$ of Glassmilk suspension (Bio101, California, USA). After pelleting and washing with $70 \%$ (vol $/ \mathrm{vol}$ ) ethanol, DNA was eluted in $250 \mu$ distilled water; $50 \mu \mathrm{l}$ of the DNA preparation was used for plasma PCR.

\section{POLYMERASE CHAIN REACTION}

The two-tube nested PCR assay was modified from a published protocol. ${ }^{11}$ All DNA extracts and controls were denatured at $95^{\circ} \mathrm{C}$ for 15 minutes and chilled in ice for five minutes. For initial amplification with $0.5 \mu \mathrm{M}$ external primers (CMTR1 5'-CTGTCGGTATGGT CTCTTC-3', CMTR2 5'-CCCGACACGCG GAAAAGAAA-3') (Applied Biosystems model 380A synthesiser, Applied Biosystems, California, USA), the PCR mixture $(100 \mu \mathrm{l})$ contained denatured peripheral blood leucocytes or plasma DNA, PCR buffer $(10 \mathrm{mM}$ Tris- $\mathrm{HCl}$ $\mathrm{pH} 8.3,50 \mathrm{mM} \mathrm{KCl}, 3 \mathrm{mM} \mathrm{MgCl}$, and $0.01 \%$ gelatin), $200 \mu \mathrm{M}$ of each deoxynucleoside triphosphates (dNTPs), and $2.5 \mathrm{U}$ Taq polymerase (Perkin-Elmer Cetus, Norwalk, USA). Each sample was amplified in 30 cycles of $94^{\circ} \mathrm{C}$ for one minute, $55^{\circ} \mathrm{C}$ for one minute, and $72^{\circ} \mathrm{C}$ for one minute, and with a final extension at $72^{\circ} \mathrm{C}$ for 10 minutes in an automated thermal cycler (Perkin-Elmer Cetus, Gouda, The Netherlands). For subsequent amplification with $0.5 \mu \mathrm{M}$ internal primers (CMTR3 5'-TCTCTGGTCCTGA TCGTCTT-3', CMTR4 5'-GTGACCTACC AACGTAGGTT-3') (Applied Biosystems model 380A synthesiser), $10 \mu \mathrm{l}$ of the first PCR product was transferred to a new PCR reaction mixture of the same composition and final volume as before. The PCR conditions for denaturation, annealing, and extension, as well as the number of cycles, were as outlined above. Cloned amplicon, a construct with the segment of the morphological transforming region II (mtr II) gene of CMV amplified by CMTR1 and CMTR2 cloned into pUC19 (Boehringer Mannheim, Germany), and distilled water were used as the positive and negative controls, respectively. Procedures for avoiding false positive results were followed strictly. ${ }^{12}$ To minimise false negative results due to the presence of inhibitors in the samples, a $\beta$ globin control was included in parallel with every sample in the leucocyte PCR assay, ${ }^{13}$ and a control spiked with 100 copies of CMV DNA accompanied each clinical sample in the plasma PCR assay.

DETECTION AND CONFIRMATION OF AMPLIFIED PRODUCTS

Ten microlitres of each final PCR product were electrophoresed in 2\% (wt/vol) agarose gel (Promega, Madison, USA), with a molecular size marker ( $\Phi \mathrm{X}-174$ DNA Hae III digest; Promega, Madison, USA) in parallel. Electrophoresis in Tris-borate-EDTA (TBE) buffer was performed at $120 \mathrm{~V}$ for one hour. The gel was stained with ethidium bromide $(0.5 \mu \mathrm{g} / \mathrm{ml})$ for 15 minutes, rinsed, and photographed under ultraviolet light illumination. A $168 \mathrm{bp}$ fragment located within the morphological transforming region II (mtr II) of the CMV genome was generated in positive samples. ${ }^{14}$ 

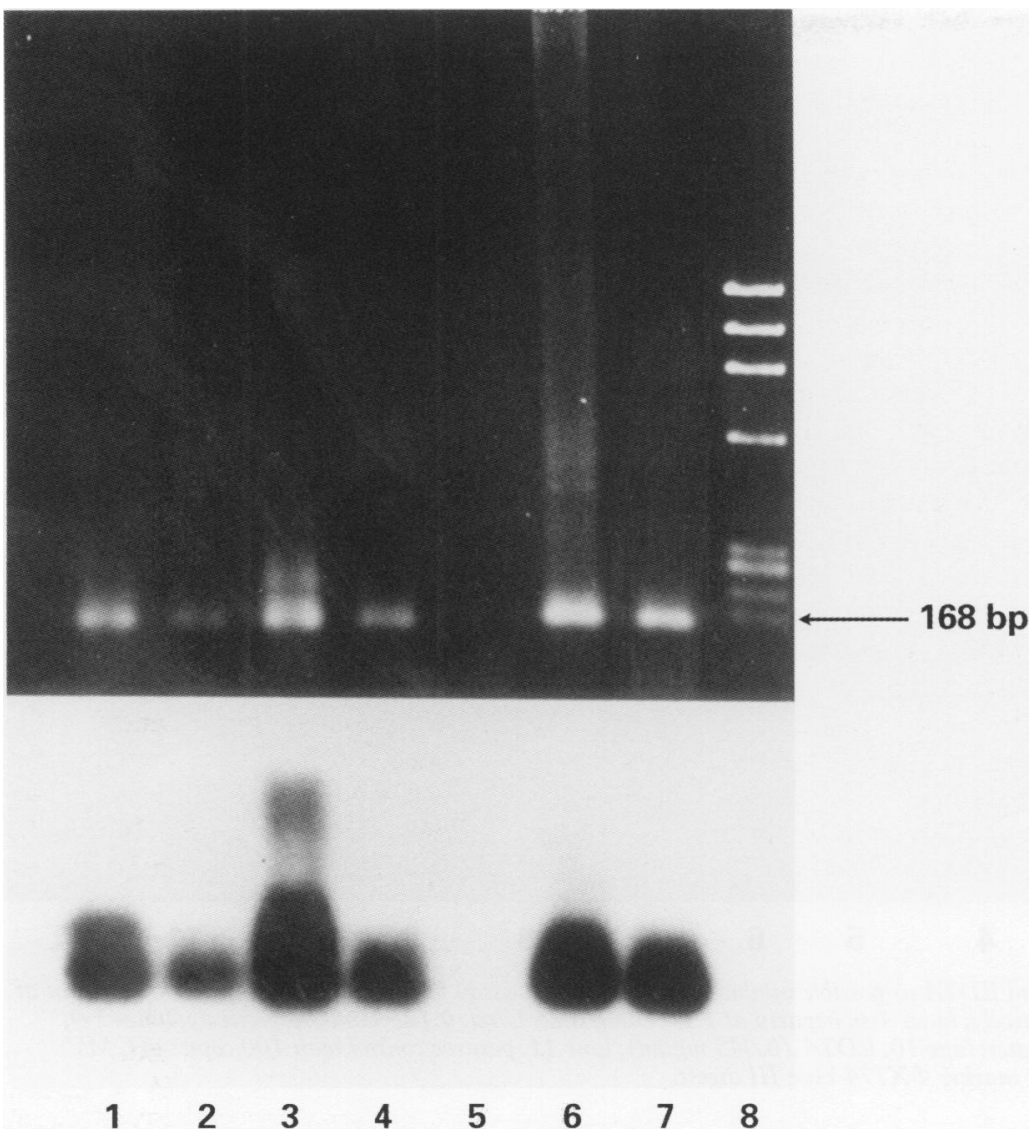

Figure 1 Detection of CMV DNA. DNA products from the nested peripheral blood leucocyte PCR were electrophoresed on a $2 \%$ agarose gel (top) and probed by Southern hybridisation (bottom) with an oligonucleotide probe containing a DNA sequence internal to primer sequence used in the nested PCR. Lanes 1 and 3, positive controls with 100 copies of CMV genome; lane 5, negative control containing distilled water; lanes $2,4,6$, and 7 blood samples taken from separate patients; lane 8 , molecular marker: $\varphi X 174 \mathrm{Hae}$ III digest. Results of the gel electrophoresis agree with those obtained by the Southern blot. The arrows indicate the PCR product of $168 \mathrm{bp}$.

Table 1 Comparison of the sensitivity and specificity of PBL and plasma PCR assays with reference to conventional CMV culture

\begin{tabular}{llll}
\hline & & \multicolumn{2}{l}{ Conventional CMV culture } \\
PCR assay & & $\begin{array}{l}\text { Number (\%) with } \\
\text { positive viraemia }\end{array}$ & $\begin{array}{l}\text { Number (\%) with } \\
\text { negative viraemia } \\
(\mathrm{n}=15)\end{array}$ \\
\hline Type & Result & $(\mathrm{n}=202)$ \\
\hline PBL PCR & Positive & $15(100)^{\star}$ & $59(29) \dagger$ \\
Plasma PCR & Negative & $0(0)$ & $143(71)$ \\
Simple extraction & Positive & $9(60)^{\star}$ & $21(10) \dagger$ \\
Instagene extraction & Negative & $6(40)$ & $181(90)$ \\
Geneclean extraction & Positive & $10(67)$ & $24(12)$ \\
& Negative & $5(33)$ & $178(88)$ \\
& Positive & $4(27)$ & $194(96)$ \\
\hline
\end{tabular}

${ }^{\star} \mathrm{p}<0.01$ by $\chi^{2}$ test.

$\dagger \mathrm{p}<0.001$ by $\chi^{2}$ test.
$(0.15,0.03$, and $0.015 \%$ (wt/vol)), and EDTA $(0.045 \mathrm{mg} / \mathrm{ml})$ were used to determine the possible inhibitory effect of these substances on the CMV PCR reactions; $1.25 \mathrm{U} / \mathrm{ml}$ heparin, $0.15 \%$ dextran, and $0.045 \mathrm{mg} / \mathrm{ml}$ EDTA corresponded to the final concentrations of these substances in routine plasma PCR experiments using heparinised or EDTA blood samples.

\section{STATISTICS}

The results were compared using the $\chi^{2}$ test (Sigmastat for Windows 1.0). A p value of $<$ 0.05 was considered statistically significant.

\section{Results}

Conventional CMV culture was used as the gold standard to detect the presence or absence of viraemia in patients. Fifteen samples obtained from eight patients were positive by conventional CMV culture (with an onset of CMV viraemia ranging from day 24 to day 94 (median day 59) after transplantation), of which all were positive for CMV DNA as detected by the peripheral blood leucocyte PCR assay (fig 1), achieving a sensitivity of $100 \%$ (table 1). Among these 15 specimens, only nine were positive for CMV DNA as detected by the plasma PCR assay using simple extraction, representing a sensitivity of $60 \%$. In the remaining 202 blood samples with negative CMV culture result, $59(29 \%)$ and $21(10 \%)$ were positive for CMV DNA as detected by the leucocyte PCR and plasma PCR assays, respectively, with corresponding specificities of 71 and $90 \%$ (table 1). Statistical significant differences in sensitivity $(\mathrm{p}<0.01)$ and specificity $(p<0.001)$ between results obtained by leucocyte and plasma PCR were observed.

The clinical relevance of these results by PCR was correlated with episodes of CMV disease. In the eight disease episodes (represented by the 15 positive CMV cultures) among bone marrow transplant patients, plasma PCR assay would miss one completely and show delayed detection of two one week after CMV cultures became positive. In contrast, leucocyte PCR assay did not miss any disease episode. However, false positives were detected. The peripheral blood leucocyte and plasma PCR assays were positive in 15 and four patients, respectively, in whom cultures for CMV had never been positive.

The possibility of reduced or zero amplification due to the presence of inhibitors in heparinised blood samples was investigated. For plasma PCR, inhibitor was present in 81 negative samples $(40 \%)$, as there was no amplification among the corresponding 81 samples spiked with CMV DNA. Extraction by Instagene and Geneclean reduced inhibition in negative specimens to $15 \%$ and $5 \%$, respectively, as the corresponding controls spiked with CMV DNA were amplified successfully, but neither method improved the sensitivity of plasma PCR (table 1). On the other hand, there was successful amplification of the $\beta$ globin gene in all the corresponding controls of the negative samples for leucocyte PCR, showing that inhibitor was absent in these samples. 


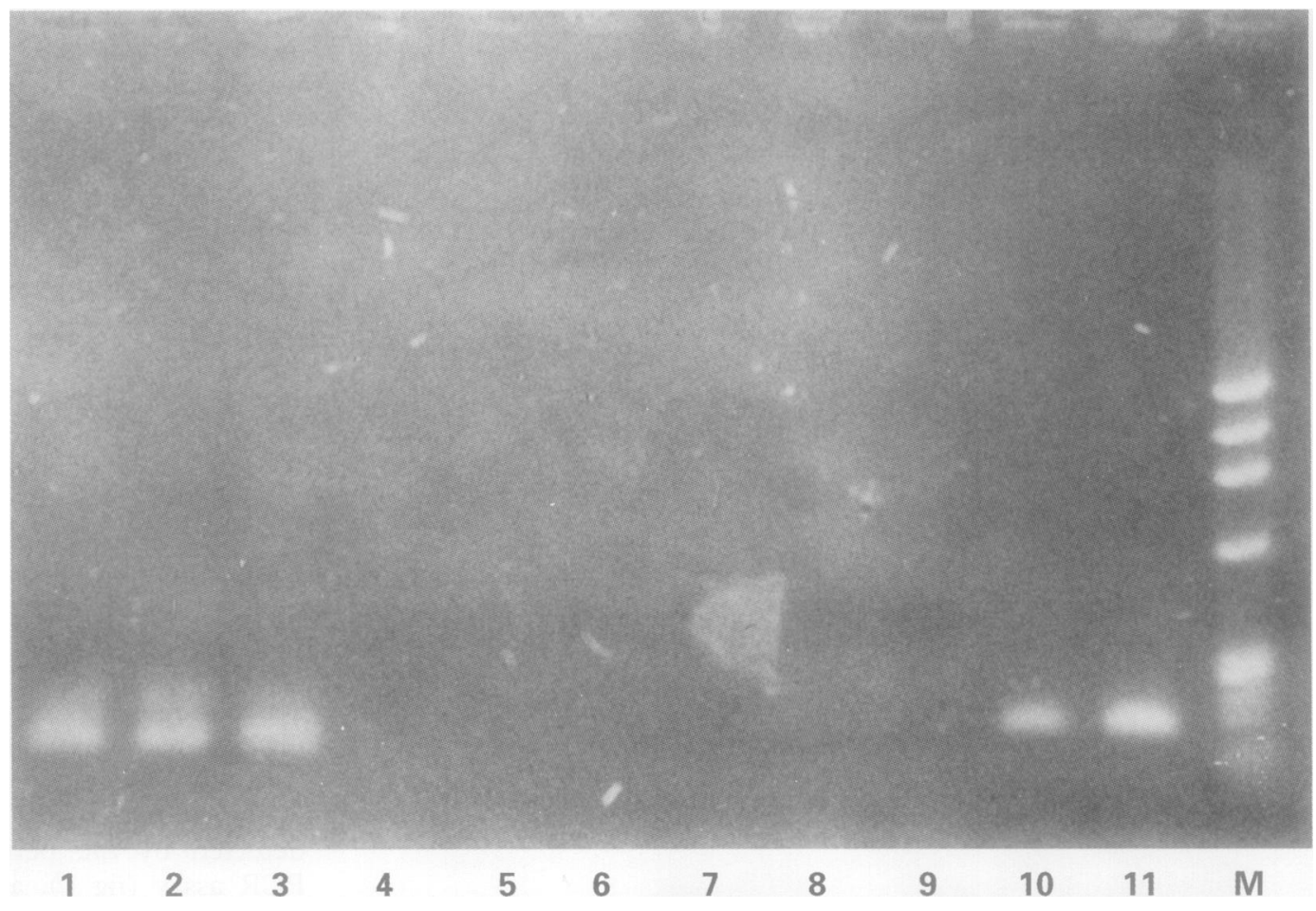

Figure 2 Dextran, heparin, and EDTA as possible inhibitors of nested PCR assay for CMV DNA. Lanes 1-3, dextran at $0.15 \%, 0.03 \%, 0.015 \%$, respectively; lanes 4-6, heparin at $1.25 \mathrm{U} / \mathrm{ml}, 0.25 \mathrm{U} / \mathrm{ml}, 0.125 \mathrm{U} / \mathrm{ml}$, respectively; lanes 7-9, negative control with distilled water; lane $10, E D T A(0.045 \mathrm{mg} / \mathrm{ml})$; lane 11 , positive control with 100 copies of CMV $D N A$; lane $M, D N A$ molecular marker $\Phi X 174$ Hae III digest.

The effect of heparin, dextran, and EDTA on the amplification of control CMV DNA by nested PCR is shown in fig 2. Dextran and EDTA did not interfere with the assay. However, heparin was profoundly inhibitory even when diluted to 10 -fold its usual concentration in the reaction mix for plasma PCR $(0.0125 \mathrm{U} / \mathrm{ml})$.

\section{Discussion}

The development of a rapid, minimally invasive, and highly sensitive method in a routine laboratory for screening bone marrow transplant patients for the presence of CMV disease is crucial in deciding to whom ganciclovir should be given. In our bone marrow transplant patients, detection of CMV DNA using peripheral blood leucocytes obtained from heparinised blood for PCR achieved a sensitivity of $100 \%$, which makes the assay a suitable method for screening CMV disease in bone marrow transplant patients. If the leucocyte CMV PCR assay is negative for a particular patient, one may conclude with confidence that the patient is unlikely to have an active CMV disease. All patients tested positive by this method must be further assessed by other assays for CMV disease (for example, pp65 antigenaemia assay ${ }^{7}$ or shell vial culture for detection of early antigen expression ${ }^{3}$ ), as well as looking for clinical signs and symptoms of CMV disease.

Both plasma and leucocytes obtained from peripheral blood anticoagulated with either heparin or EDTA have been used for the detection of CMV DNA by PCR assay in patients with or without bone marrow transplants, but conflicting results have been reported and no conclusion on the most appropriate source of CMV DNA has been reached..$^{67-23}$ In one study with bone marrow transplant patients in which plasma obtained from heparinised blood was used, a sensitivity of $100 \%$ was reported compared to conventional CMV culture, though the assay was not performed in parallel with a peripheral blood leucocyte PCR assay. ${ }^{6}$ On the other hand, two studies on bone marrow transplant patients showed that CMV DNA was often detected in leucocytes before the onset of CMV disease, and CMV DNA in plasma samples was usually detected after the onset of CMV disease. ${ }^{22}{ }^{23}$ Nevertheless, neither of these reports mentioned the type of anticoagulant used in their blood samples, nor the possibility of any inhibitor problem. In our study, when heparinised blood was used the sensitivity of the peripheral blood leucocyte PCR assay $(100 \%)$ was significantly higher than that of the plasma PCR assay (60\%).

Heparin, which had a profoundly inhibitory effect on the PCR reactions even at 0.0125 $\mathrm{U} / \mathrm{ml}$ (fig 2), is likely to contribute to the relatively low sensitivity and the inhibitor problem in the negative samples of plasma PCR assays. It has been reported that heparin is an exogenous inhibitor to PCR assays in at least three studies. ${ }^{8-10}$ In one study, heparinase was reported to be effective in eliminating the inhibitory effect of heparin, but heparinase treatment must be followed by treatment with $\mathrm{Ca}^{2+}(1.3 \mathrm{mM})$ and glycol-etherdiamine-tetraacetic acid (EGTA, $13.5 \mathrm{mM}$ ), but an EGTA concentration of above $5 \mathrm{mM}$ would inhibit PCR. ${ }^{10}$ Therefore heparinase treatment of the heparinised blood samples would not be feasible in our CMV PCR assay. On the other hand, heparin did not seem to interfere with the 
peripheral blood leucocyte PCR assay, as all heparin in the blood was removed after rinsing in PBS and suspending the pellet in distilled water.

Besides heparin, plasma itself inhibits PCR (unpublished observation). It has been reported that endogenous PCR inhibitors are present in different clinical samples such as urine, stool, sputum, vitreous fluid, aqueous fluid, and other body tissues, and various methods including dilution, phenolchloroform extraction, column extraction immunomagnetic separation, guanidium thiocyanate extraction, capture resin, and dialysis gel purification could be used to reduce the inhibitory effects. ${ }^{11}{ }^{24-29}$ In our study, although most of the inhibitor problem was removed after Instagene or Geneclean extraction, a failure in improving the sensitivities of the PCR assays might be related to the loss of significant proportion of CMV DNA during extraction.

Apart from the inhibitor problem in plasma PCR, another reason for the relatively higher sensitivity of the peripheral blood leucocyte PCR is the larger amount of template in leucocytes than in plasma. The plasma was diluted in turn by dextran and lysing buffer, with or without purification matrix, before PCR, whereas a fixed number of leucocytes $\left(2 \times 10^{6}\right.$ cells/ml) was used for the leucocyte PCR. Furthermore, the concentration of CMV DNA in leucocytes was higher than in plasma, as CMV replicates actively in peripheral blood leucocytes.

In order to achieve the best possible results, an adequate concentration of leucocytes has to be added to the PCR mixture. Manual counting of cells by haemocytometer is labour intensive and time consuming when the number of samples for processing is high. An alternative would be to use automated methods, such as the Coulter counter or flow cytometry for cell counting, ${ }^{30}$ which would increase the feasibility of PCR assay using leucocytes as a routine diagnostic assay.

In conclusion, detection of CMV DNA by nested PCR using peripheral blood leucocytes is more sensitive than using plasma from heparinised blood in bone marrow transplant recipients. Therefore leucocyte PCR, which can be completed within 10 hours, is a more useful screening test in helping to decide on the group of bone marrow transplant recipients to whom ganciclovir should be given.

1 Sable CA, Donowitz GR. Infections in bone marrow transplant recipients. Clin Infect Dis 1994;18:273-84.

2 Meyers JD, Flournoy N, Thomas ED. Risk factors for cytomegalovirus infection after human bone marrow transplantation. F Infect Dis 1986;153:478-88.

3 Meyers JD, Ljungman P, Fisher LD. Cytomegalovirus excretion as a predictor of cytomegalovirus disease after bone marrow transplantation: importance of cytomegalobone marrow transplantation: importance
virus viremia. $\mathcal{F}$ Infect Dis 1990;162:373-80.

4 Schmidt GM. Horak DA, Niland JC, Duncan SR, Forman SJ, Zaia JA. A randomised, controlled trial of prophylactic SJ, Zaia JA. A randomised, controlled trial of prophylactic ganciclovir for cytomegalovirus pulmonary infection in

5 Spector SA, Merrill R, Wolf D, Danker WM. Detection of human cytomegalovirus in plasma of AIDS patients during acute visceral disease by DNA amplification. $f$ Clin Microbiol 1992;30:2359-65.

6 Wolf DG, Spector SA. Early diagnosis of human cytomegalovirus disease in transplant recipients by DNA amplification in plasma. Transplantation 1993;56:330-4.

7 Freymuth F, Gennetay E, Petitjean J, Eugene G, Huranlt De Ligny B, Ryckelynck J-P, et al. Comparison of nested PCR for detection of DNA in plasma with pp65 leukocytic antifor detection of DNA in plasma with pp65 leukocytic antigenemia procedure for diagnosis of human cyton

8 Beutler E, Gelbart T, Kuhl W. Interference of heparin with the polymerase chain reaction. Biotechniques 1990;9:166.

9 Poli F, Cattaneo R, Crespiatico L, Nocco A, Sirchia G. A rapid and simple method for reversing the inhibitory effect of heparin on PCR for HLA Class II typing. PCR Methods Appl 1993;2:356-8.

10 Imai $H$, Yamada $O$, Morita $S$, Suehiro $S$, Kurimura $T$ Detection of HIV-1 RNA in heparinized plasma of HIV-1 seropositive individuals. $\mathcal{F}$ Virol Methods 1992;36:181-4.

11 Khan G, Kangro HO, Coates PJ, Heath RB. Inhibitory effects of urine on the polymerase chain reaction for cytomegalovirus DNA. F Clin Pathol 1991;44:360-5.

12 Kwok S, Higuichi. Avoiding false positive with PCR. Nature 1989;339:237-8.

13 Saiki RK, Scharf S, Faloona F. Enzymatic amplification of $\beta$-globin genomic sequences and restriction site analysis for $\beta$-globin genomic sequences and restriction site analysis for
diagnosis of sickle cell anaemia. Science 1985;230:1350-4.

14 Razzaque A, Jahan N, McWeeney D, Jariwalla RJ, Jones C, Brady J, et al. Localization of DNA sequence analysis of the transforming domain (mtr II) of human cytomegalovirus. Proc Natl Acad Sci USA 1988;85:5709-13.

15 Sambrook J, Fritsch EF, Maniattis T, eds. Molecular cloning. a laboratory manual. New York: Cold Spring Harbour Press, 1989.

16 Brutting M, Xu W, Wahren B, Sundqvist VA. Cytomegalovirus DNA detection in sera from patients with active cytomegalovirus infections. $\mathcal{F}$ Clin Microbiol 1992;30:1937cytom.

17 Cassol SA, Poon MC, Pal R, Naylor MJ, Culver JJ, Bowen TJ, et al. Primer-mediated enzymatic amplification of cytomegalovirus (CMV) DNA: application to the early diagnosis of CMV infection in marrow transplant recipients. F Clin Invest 1989;83:1 109-15.

18 Zipeto D, Morris S, Hong C, Dowling A, Wolitz R, Merigan TC, et al. Human cytomegalovirus (CMV) DNA in plasma reflects quantity of CMV DNA present in leukocytes. $7 \mathrm{Clin}$ Microbiol 1995;33:2607-11.

19 Schmidt CA, Oettle H, Peng R, Neuhaus P, Blumhardt, G, Lohmann $\mathrm{R}$, et al. Comparison of polymerase chain reaction from plasma and buffy coat with antigen detection and occurrence of immunoglobin $M$ for the demonstration of cytomegalovirus infection after liver transplantation. Transplantation 1995;59:1133-8.

20 Gerna G, Furione M, Baldanti F, Sarasini A. Comparative quantitation of human cytomegalovirus DNA in blood leukocytes and plasma of transplant and AIDS patients. 7 Clin Microbiol 1994:32:2709-17.

21 Nana GW, Spector SA. Early diagnosis of human cytomegalovirus disease in transplant recipients by DNA amplification in plasma. Transplantation 1993;56:330-4.

22 Brytting M, Mousavi-Jazi M, Bostrom L, Larsson M, Lunderberg J, Ljungman P, et al. Cytomegalovirus DNA in peripheral blood leukocytes and plasma from bone marrow transplant recipients. Transplantation 1995;60:961-5.

23 Bostrom L, Brytting $M$, Mousavi-Jazi $M$, Ringden $O$ Ljungman P, Lonnqvist $\mathrm{B}$, et al. PCR detection of CMV DNA in peripheral blood leukocytes and plasma from bone DNA in peripheral blood leukocytes and plasma from bone marrow

24 Amicosante M, Richeldi L, Trenti G, Paone G, Campa M, Bisetti A, et al. Inactivation of polymerase inhibitors for Mycobacterium tuberculosis DNA amplification in sputum by using capture resin. $\mathcal{F}$ Clin Microbiol 1995;33:629 30.

25 Stacy-Phipps S, Mecca JJ, Weiss JB. Multiplex PCR assay and simple preparation method for stool specimens detect enterotoxigenic Escherichia coli DNA during course of infection. F Clin Microbiol 1995;33:1054-9.

26 Wiedbrauk DL, Werner JC, Drevon AM. Inhibition of PCR by aqueous and vitreous fluids. $\mathcal{F}$ Clin Microbiol 1995;33: 2643-6.

27 Johnson SR, Martin DH, Cammarata C, Morse SA. Alterations in sample preparation increase sensitivity of PCR assay for diagnosis of chancroid. F Clin Microbiol 1995;33: 1036-8.

28 Vignoli C, de-Lamballerie X, Zandotti C. Advantage of a rapid extraction method of HIV1 DNA suitable for polymerase chain reaction. Res Virol 1995;146:159-62.

29 Herbrink P, Van Den Munckhof HAM, Niesters HGM, Goessens WH, Stolz E, Quint WG, et al. Solid-phase C1qdirected bacterial capture followed by PCR for detection of Cirected bacterial capture followed by PCR for detection of Chlamydia trach

30 Dawson $M$. Initiation and maintenance of cultures. In: $\mathrm{Cell}$ culture. Oxford: Blackwell Scientific Publications, 1992:2542. 